Journal of Primary Education
$9(3)(2020): 295-302$
UNNES
https://journal.unnes.ac.id/sju/index.php/jpe

\title{
The Influence of Literacy and Read Aloud Activities on the Early Childhood Education Students' Receptive Language Skills
}

\author{
Lely Diah Eko Priyantini ${ }^{\bowtie}$, Amin Yusuf \\ DOI: https://doi.org/10.15294/jpe.v9i3.39216 \\ Pascasarjana, Universitas Negeri Semarang, Indonesia
}

\begin{tabular}{l} 
Article Info \\
\hline History Articles \\
Received: \\
24 February 2020 \\
Accepted: \\
27 March 2020 \\
Published: \\
31 May 2020 \\
\hline Keywords: \\
Literacy Activities, \\
Read Aloud Activities, \\
Receptive Language \\
Skills
\end{tabular}

\begin{abstract}
Stimulation on language development aspects is greatly needed since humans' life may not be separated from language use and acquisition. This research aims at examining the influence of literacy and read aloud activities on the early childhood education students' receptive language skills. This research is a correlational quantitative study conducted with a survey approach. The research population was the students of Early Childhood Education Institutions in South Purwokerto District, Banyumas Regency. There were 54 Early Childhood Education Institutions in South Purwokerto District divided into 7 groups/clusters. The sampling of this research was conducted by using the Slovin's formula with the total samples of 115 students of Early Childhood Education Institutions. The data was collected through observation and then descriptively analyzed in percentages using multiple regression analysis supported with SPSS 23.0. The research results showed that literacy activities influenced the Early Childhood Education students' receptive language skills with the t-count value of 6.620 at the significance of 0.000 . Read aloud activities also influenced the Early Childhood Education students' receptive language skills with the t-count value of 8.066 at the significance of 0.000 . Literacy and read aloud activities significantly influenced the Early Childhood Education students' receptive language skills with the f-count value of 70.386 at the significance of 0.000 and the total influence of $55.5 \%$. Thus, it is suggested that literacy and read aloud activities should be continuously made to improve the Early Childhood Education students' receptive language skills.
\end{abstract}

\footnotetext{
Correspondence address:

Pascasarjana, Universitas Negeri Semarang, Indonesia

Jalan Kelud Utara III, Semarang, Jawa Tengah, Indonesia

p-ISSN 2252-6404

e-ISSN 2502-4515

E-mail: lelydiah03@gmail.com
} 


\section{INTRODUCTION}

One important aspect in the early childhood education students to stimulate is that related to language development. Early childhood language education is greatly important to develop the cognitive and learning skills which significantly influence their simultaneous education (Hasanah, 2018). Thus, language skills should be developed since early childhood (Kurnia et al., 2015). Stimulation to the aspect of language development is greatly required as the humans' life may not be separated from language use and acquisition.

The language development achievement levels of children aged 4-6 years old are divided into 3 parts: understanding language, expressing language, and literacy (Nasional, 2009). According to Vygotsky (1986) early childhood, especially those at the age of 2-7 years old, is considered at the pre-operational stage. Language is a means of human communication to have interactions (Aniati, 2017; Susilaningsih et al., 2018). Language is a result of culture which should be learned and taught. Through language, the culture of a country may be supervised, developed, and passed down to the next generations.

Various factors including genetics, environments, and communication changes may influence the speaking abilities. According to Santrock (2007), conversation and communication require some language skills that should be well mastered by the children. Those language skills include listening, speaking, reading, and writing (Anjarsari et al., 2013; Nurlohot, 2017)

Someone may be considered having good language skills when he/she is competent in selecting language voices (in the form of words, sentences, stress, and intonation) and then properly formulate them to deliver thoughts, feelings, ideas, facts, actions in certain communication contexts (Nisa' et al., 2018)

Language skills consist of four aspects: listening, speaking, reading, and writing (Nuryani, 2018). Those four aspects are categorized as receptive and productive language skills (Moeslichatoen, 2004). Receptive language skills are those implemented to understand something through spoken and written language (Adini, 2016).

A child has basically implemented his/her language skills since childhood (listening and speaking) before learning reading and writing (Bingham \& Terry, 2013). According to Goldstein \& Wetherby (1984), children's response tendency and stimulus role have facilitated the receptive language development between the individual norms. The utilization of learning media in the form of magnified letters/alphabets, interesting pictures, and vocabularies commonly found by children may attract their attention that they are interested in performing activities during the learning processes (Fitriani et al., 2019).

The development of receptive language skills is influenced by the literacy intervention made by the schools in supporting the children's language development (Lonigan et al., 2011). Literacy is one important factor in the early childhood language development to stimulate (Husnaini, 2018). Children's literacy development should be integrated with the development of children's other competences (Wirman et al., 2018)

Literacy may be defined as a development of reading and writing or a creative action in understanding a text and development of reading and writing (Lemos, 2002). According to Sari (2017), literacy should be well developed since it is a basic model for children to learn and obtain knowledge when they start entering their school ages.

The components of literacy according to Bingham \& Terry (2013) include: phonemic awareness, knowledge on alphabetic forms, as well as knowing and understanding books. The children's reading success at primary schools may be predicted from their basic literacy competences. Reading and writing as well as and early literacy competences at preschool initial stages have an important role in a child's life, especially for his/her academic success (Wilson \& Lonigan, 2010). 
Children who start going to school with limited initial literacy competences are frequently unable to catch up those with stronger initial literacy competences (Alexander et al., 1988; Juel, 1988). The children's initial literacy skills tend to remain the same when entering kindergarten and gradually increase at the primary school for years (Cabell et al., 2011). In their early childhood, children may have a significant initial literacy success when they receive a comprehensive language and literacy learning (Bingham \&-Terry, 2013).

Reading aloud is a reading activity with a loud voice reading technique that children may focus better and pay more attention (Mahartika \& Dewantoro, 2017). According to Ustianingsih et al. (2016), reading aloud is beneficial since children may share their fun experience and gives them opportunities to discuss their reading. Irfadila (2014) argues that the activity of reading aloud is greatly necessary since providing various benefits, such as building knowledge, developing learners' language skills, and facilitating learners related to their ability in listening, understanding a text, improving to recognize words, and expressing words. McGee \& Schickedanz (2007) mentioned that an effective reading aloud activity covers a systematic approach combining the teacher's higher thinking orders modeling, asking necessary questions leading to analytical conversations, encouraging children to memorize stories with certain methods.

This research aims at describing and analyzing the influence of literacy and read aloud activities on the early childhood's receptive language skills.

\section{METHOD}

This research was classified into correlational quantitative research study with a survey approach. A survey research was conducted to know certain perceptions, attitudes, and behaviors as well as to examine the existing facts and those previously conducted by the research subjects to obtain the data scales of receptive language skill, literacy activity, and read aloud.

The population of this research was the Early Childhood Education Students in South Purwokerto District, Banyumas Regency. There were 54 Early Childhood Education institutions in South Purwokerto District which were divided into 7 groups/clusters. 138 samples were collected from Early Childhood Education Institutions of PAUD Wadas Kelir, TK Diponegoro 173 Teluk, TK Aisyiyah XV Teluk, and TK IT Al Irsyad Purwokerto using a cluster random sampling with a two-stage cluster random sampling.

The research variables consist of literacy activity as independent variable (X1), Read Aloud activity also as independent variable (X2), and receptive language skills as dependent variable (Y) as in Figure 1.

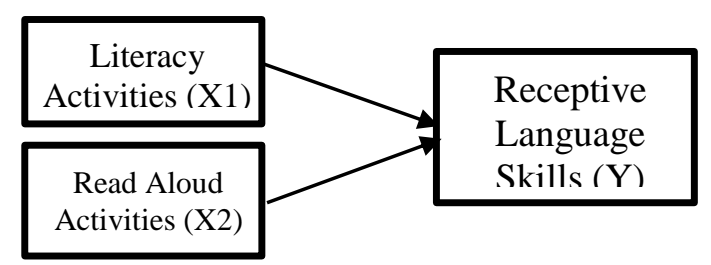

Figure 1. Research framework

The data collection related to receptive language skills as well as literacy and read aloud activities in this research used an observation technique. Before assessing the early childhood education students' receptive language skills, the researchers read the stories in accordance with the activity topics. Furthermore, the researchers observed the children's activities and made various measurements based on the established scales on variables.

The obtained data was then descriptively analyzed in percentages. The hypothetical test was initially made with the assumption tests covering normality, heteroscedasticity, and multicollinearity test using the computer software program of SPSS (statistical Program of Social Science) v.23 for windows. 


\section{RESULTS AND DISCUSSION}

This research consisted of independent variables (literacy and read aloud activities) and dependent variable (receptive language skills). The descriptive analysis is explained in Figure 2.

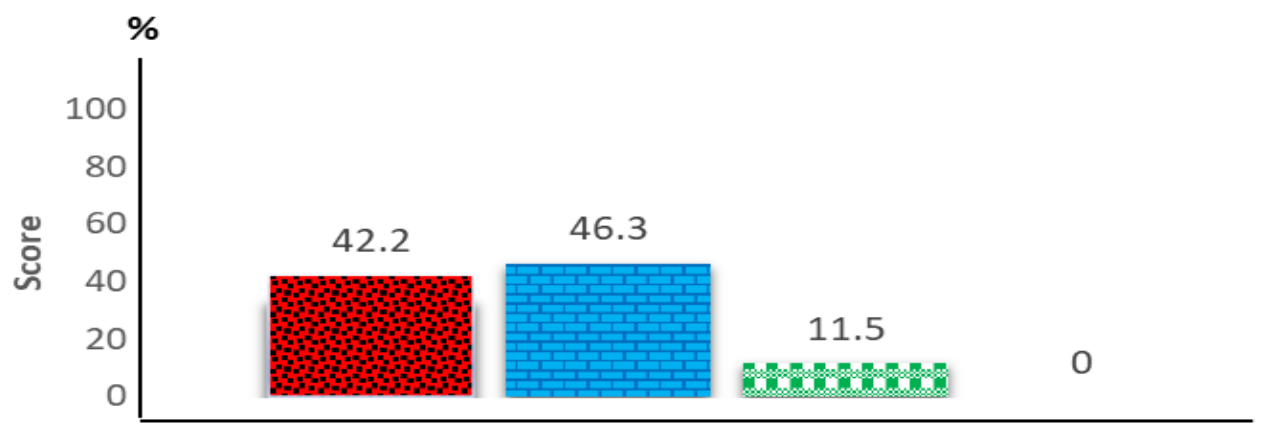

Receptive Language Skills

a Consistently developing Developing as expected

Start developing Not yet developing

Figure 2. Early Childhood Education Students' Receptive Language Skills

Based on the results presented in Figure 2 related to the Early Childhood Education Students' receptive language skills, the percentages of receptive language skills were obtained and respectively categorized into consistently developing by $72.46 \%$, developing as expected by $17.39 \%$, start developing by $9.42 \%$ and not yet developing by $0.72 \%$. The average score of Early Childhood Education
Students' receptive language skills was categorized into developing as expected by 83.3\% which meant that the Early Childhood Education students were able to re-express the story plots read by the teacher, understand the rules and commands, obey the rules without the teachers' commands, and follow two commands given at the same time. Descriptive data of literacy activities was presented in Figure 3.

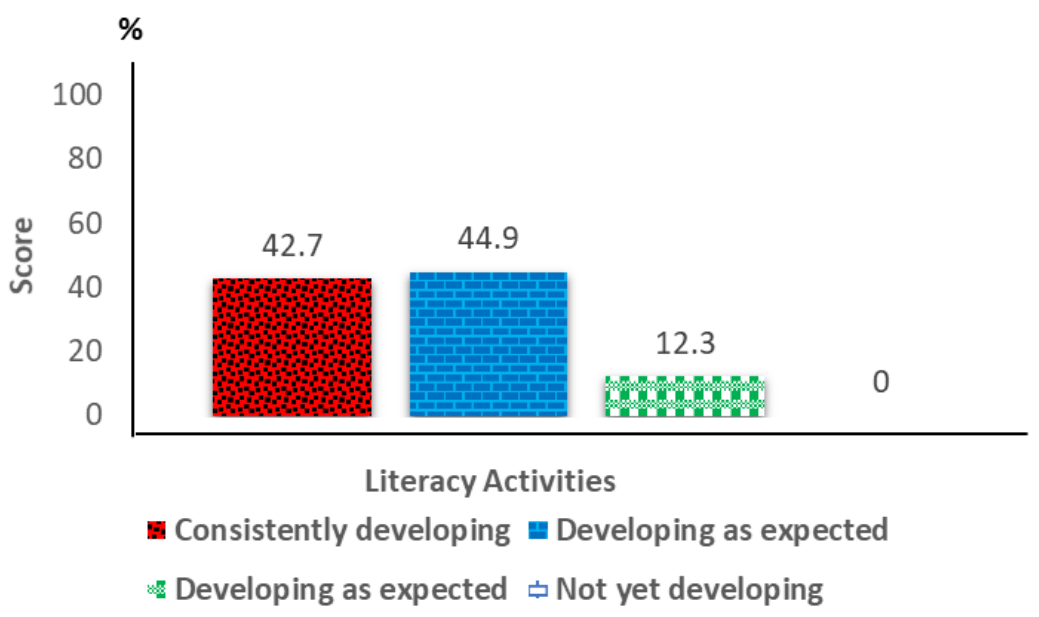

Figure 3. Graph of Early Childhood Education Students' Literacy Activities

Based on the results presented in Figure 3 related to the Early Childhood Education Students' literacy activities, the percentages of Early Childhood's literacy activities were obtained and respectively categorized into consistently developing by $67.39 \%$, developing as expected by $28.26 \%$, start developing by $4.35 \%$, and not yet developing by no Early 
Childhood's literacy activities. The average score of Early Childhood Education Students' literacy activities was categorized into developing as expected by $82.7 \%$ which meant that the Early Childhood Education students started able to classify the voice similarities and differences, understand the appearing printed items on books, such as picture, start learning various forms of writing acceptable although the alphabets still randomly appeared, and start talking with simple sentence patterns. Meanwhile, the variable of read-aloud activities was presented in details in Figure 4.

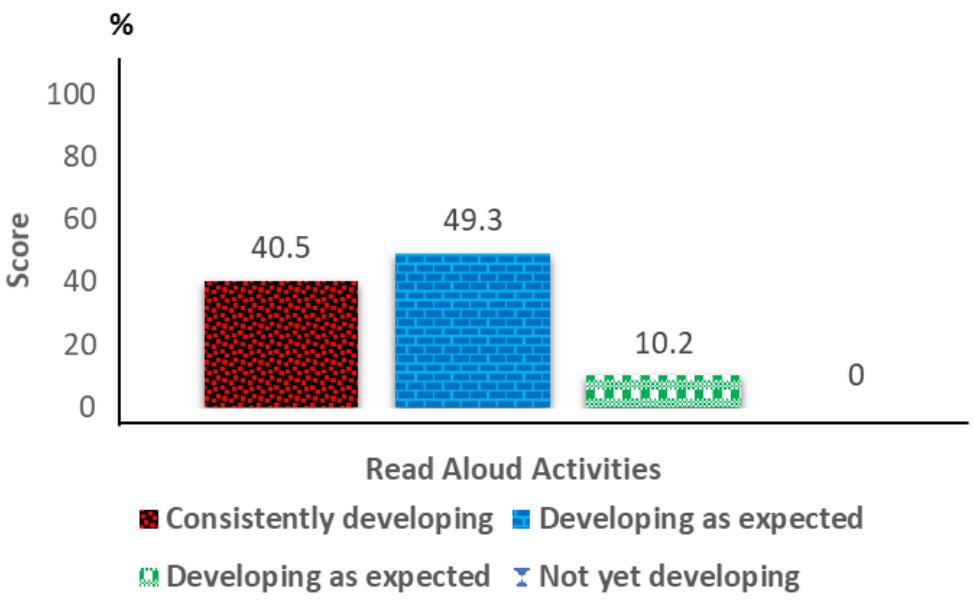

Figure 4. Graph of Early Childhood Education Students' Read Aloud Activities

Table 1. Regression Hypothetical Test

Based on the results presented in Figure 4 related to the Early Childhood Education Students' read aloud activities, the percentages of read aloud activities were obtained and respectively categorized into consistently developing by $70.01 \%$, developing as expected by $18.84 \%$ and start developing by $9.42 \%$, and not yet developing by $0.72 \%$. The average score of Early Childhood Education Students' read aloud activities was categorized into developing as expected by $82.4 \%$ which meant that the Early Childhood Education students were interested in taking care the books yet not consistent, the children voices when reading were heard by others, and they showed serious expressions but without a full willingness to read.

In hypothetical testing, the assumption tests were first conducted. Those assumption tests included normality, heteroscedasticity, and multicollinearity test. After conducting the assumption tests, regression test was conducted to figure out the influence of literacy activity and read aloud on the students' receptive language skill. The results were presented in Table 1.

\begin{tabular}{lll}
\hline Variable & $\mathrm{T}$ & Sig. \\
\hline Literacy activities & 6.620 & 0.000 \\
Read Aloud activities & 8.066 & 0.000 \\
\hline
\end{tabular}

Based on Table 1, the results showed that the variable of literacy activities influenced the receptive language skills with the value of tcount $>$ ttable by $6.620>0.674$ and significance value in the significance column (2-tailed) by $0.000<0.05(5 \%)$. Based on the results of data analysis above, it might be concluded that $\mathrm{Ha}$ was accepted which meant that literacy activities influenced the receptive language skills.

Furthermore, the influence of read aloud activities on receptive language skills was seen from the value of tcount $>$ ttable by $8.066>0.674$ and the significance value in the significance column ( 2 -tailed) by $0.000<0.05(5 \%)$. Based on the results of data analysis, it might be concluded that Ha was accepted which meant that read aloud activities influenced receptive language skills.

The simultaneous tests showed that literacy and read aloud activities influenced the early childhood education students' receptive 
language skills with the value of Fcount by 70.386 with the significance of 0.000 and simultaneous influence of $55.5 \%$ which meant that both literacy and read aloud activities influenced the early childhood education students' receptive language skills.

The above research results were relevant to those previously explained by Faradina (2017) that literacy activity program might improve the students' reading interest at An-Najah Integrated Islamic Primary School, Jatinom, Klaten. It showed that literacy activities influenced receptive language skills, in this case, reading interest. Reading interest is considered as one receptive language skill since children interpreted symbols found in the text. It was also stated by Safitri et al., (2019) that someone might obtain information including through a reading activity which is actually an activity to understand the writing. Reading was not only seeing a group of letters/alphabets but also understanding the meaning contained in writing. Besides, high literacy greatly influenced humans' receptive language, such as listening to information that humans might obtain various information related to their life (Muhammad, 2019).

This research also proved that what conducted by Puspitadewi \& Erny (2018) stating that literacy activity program might improve the reading and writing interest of students of State Junior High Schools in Lakarsantri District. It showed that literacy activity program influenced language skills including reading and writing. Reading and writing were classified into receptive language skills. Besides, through literacy activities, someone might improve his/her language competences including listening, speaking, reading, and writing (Sari \& Pujiono, 2017).

According to Gatot (2018), read aloud activities might improve the children's language competences including listening, speaking, reading, and writing. Read aloud might help the grade III students of primary schools in reading a text. It showed that students had receptive language skills since they were able to understand information contained in the text books (Hardianto, 2019). Besides, Agustini (2019) asserted that literacy activity at schools might improve the students' understanding on both receptive and productive language.

The more the read aloud activities are made, the better the early childhood's receptive language skills may be obtained. Those because read aloud activities might stimulate the children's responses that they might have interest and attention to get involved in the story. Strachan (2015) asserted that during the read aloud activities, the teacher gave explanations and understanding to the children, helped the children make interactions between their books and life, and stimulated the children's responses. That finding also proved the statement made by Johnston (2015) that read aloud activities used expression, voice, intonation, and gesture to attract the children's attention to get involved in the story.

\section{CONCLUSION}

Literacy and read aloud activities developed the students' ability to understand the information obtained from reading texts, stories, or other people's expressions. Thus, the higher the early childhood education students' literacy and read aloud activities, the higher the early childhood education students' receptive language skills. The Early Childhood Education Institutions and Offices are recommended to implement literacy and read aloud activities to improve the early childhood education students' receptive language skills.

\section{ACKNOWLEDGEMENT}

We would like to express our deepest gratitude to Head of Education Office, teachers, and students of Early Childhood Education Institutions in South Purwokerto District.

\section{REFERENCES}

Adini, A. L. (2016). Kemampuan Bahasa Reseptif Anak Kelompok A Gugus V 
Kecamatan Berbah. Jurnal Pendidikan Anak Usia Dini, 5(6), 600-611.

Agustini, D. (2019). Meningkatkan Pemahaman Berbahasa Melalui Program Literasi di Sekolah Dasar. PROSIDING SEMINAR NASIONAL PROGRAM PASCASARJANA UNIVERSITAS PGRI PALEMBANG, 2, 364-370.

Alexander, K. L., Entwisle, D. R., Blyth, D. A., \& McAdoo, H. P. (1988). Achievement in the First 2 Years of School: Patterns and Processes. Monographs of the Society for Research in Child Development, 53(2), i.

Aniati. (2017). Konsep Menumbuhkan Keterampilan Berbahasa Indonesia bagi Anak melalui Metode Bermain. MUSAWA, 9(12), 247-282.

Anjarsari, N., Suwandi, S., \& Mulyono, S. (2013). Analisis kesalahan pemakaian bahasa Indonesia dalam karangan mahasiswa penutur bahasa asing di Universitas Sebelas Maret. BASASTRA, 1(2), 250-262.

Bingham, G. E., \& Patton-Terry, N. (2013). Early language and literacy achievement of early reading first students in kindergarten and 1st grade in the United States. Journal of Research in Childhood Education, 27(4), 440-453.

Cabell, S. Q., Justice, L. M., Konold, T. R., \& McGinty, A. S. (2011). Profiles of emergent literacy skills among preschool children who are at risk for academic difficulties. Early Childhood Research Quarterly, 26(1), 1-14.

Faradina, N. (2017). Pengaruh Program Gerakan Literasi Sekolah terhadap Minat Baca Siswa di SD Islam Terpadu Muhamadiyah An-Najah Jatinom Klaten. Jurnal Hanata Widya, 6(3), 60-69.

Fitriani, D., Fajriah, H., \& Rahmita, W. (2019). Media Belajar Big Book dalam Mengembangkan Kemampuan Berbahasa Reseptif Anak Usia Dini. Jurnal Obsesi: Jurnal Pendidikan Anak Usia Dini, 4(1), 247.

Gatot, M. \& M. R. . (2018). Peningkatan Kemampuan Bahasa Anak melalui
Metode Read Aloud. Jurnal Obor Penmas. Jurnal Obor Penmas, 1(1), 56-66.

Goldstein, H., \& Wetherby, B. (1984). Application of a Functional Perspective on Receptive Language Development to Early Intervention. Remedial and Special Education, 5(2), 48-58.

Hardianto, H. (2019). Meningkatkan Kemampuan Siswa dalam Membaca Teks dengan Menggunakan Metode Reading Aloud di Kelas III SDN. No. 028/XI Tanjung Tahun 2017/2018. Jurnal Ilmiah Universitas Batanghari Jambi, $19(2)$, 368. https://doi.org/10.33087/jiubj.v19i2.634

Hasanah, AM, A. U. (2018). Analisis Keterlambatan dalam Perkembangan Bahasa Anak Usia Dini (Studi Kasus pada Anak kembar). Jurnal Pendidikan Dasar (JUPENDAS), 5(1), 7-16.

Husnaini, N. (2018). Identifikasi Pola Pengenalan Literasi pada Anak Usia Dini di Kota Mataram. Jurnal Pendidikan Anak Usia Dini, 7(1), 21-29.

Johnston, V. (2015). The power of the read aloud in the age of the common core. Open Communication Journal, 9(2001), 3438.

Juel, C. (1988). Learning to read and write: A longitudinal study of 54 children from first through fourth grades. Journal of Educational Psychology, 80(4), 437-447.

Kurnia, D., Mohamad, T., Endah, S. (2015). Analisis Capaian Perkembangan Bahasa Anak Usia Dini dalam Kegiatan Pembelajaran dengan Metode Learning Based Resources. Cakrawala Dini, 6(2), 89-99.

Lemos, M. D. (2002). Closing the gap between research and practice: Fondations for the acquisition of literacy. Australia: Acer.

Lonigan, C. J., Farver, J. A. M., Phillips, B. M., \& Clancy-Menchetti, J. (2011). Promoting the development of preschool children's emergent literacy skills: $A$ randomized evaluation of a literacy-focused curriculum and two professional development models. Reading and Writing (Vol. 24). 
Mahartika, A. S., \& Dewantoro, D. A. (2017). Meningkatkan Kemampuan Membaca Pemahaman Anak Tunagrahita Ringan dengan Menggunakan Metode Reading Aloud. Jurnal ORTOPEDAGOGIA, 3(2), 123-126.

McGee, L. M., \& Schickedanz, J. A. (2007). Repeated Interactive Read-Alouds in Preschool and Kindergarten. The Reading Teacher, 60(8), 742-751.

Moeslichatoen R. (2004). Metode Pengajaran Di Taman Kanak - Kanak. Jakarta: PT Asdi Mahasatya.

Muhammad, K. (2019). Kesulitan Siswa Sekolah Dasar Dalam Meningkatkan Kemampuan Literasi. Jurnal Pendidikan Almuslim, VII(2), 94-102. Retrieved from file:///D:/jurnal skripsi/literasi 2019 (jurnal) (2).pdf

Nasional, M. P. (2009). Peraturan Menteri Pendidikan Nasional Nomor 58 Tahun 2009 Tentang Standar Pendidikan Anak Usia Dini. Jakarta.

Nisa', E., Rusilowati, A., \& Wardani, S. (2018). The Analysis of Student Science Literacy in Terms of Interpersonal Intelligence. Journal of Primary Education, 8(2), 161168.

Nurlohot. (2017). Meningkatkan Kemampuan Membaca Awal Siswa melalui Permainan Bahasa di Kelas 1 SDN 012 Simangbat Kecamatan Siabu Kabupaten Mandailing Natal. JGK (Jurnal Guru Kita), 1(4), 97103.

Nuryani, N. (2018). Kompetensi Profesional Guru Bahasa Dan Sastra Indonesia. Bahastra, 38(1), 58.

Puspitadewi, C.A \& Erny, R. (2018). Pengaruh Program Literasi terhadap Minat Baca dan Tulis Siswa di SMP Negeri SeKecamatan Lakarsantri Surabaya. Inspirasi Manajemen Pendidikan, 6(2).
Safitri, L. Aji, H. M., Santhy, H. (2019). Pengaruh Membaca 15 Menit Terhadap Minat Baca Siswa Sekolah Dasar. Jurnal Cakrawala Pendas, 5(2).

Santrock, J. W. (2007). Perkembangan anak. Jakarta: Erlangga.

Sari, E. S., \& Pujiono, S. (2017). Budaya Literasi di Kalangan Mahasiswa FBS UNY. LITERA, 6(1), 105-113.

Sari, D. Y. (2017). Peran Guru dalam Menumbuhkan Literasi Melalui Bermain Pada Anak Usia Dini. Golden Age: Jurnal Pendidikan Anak Usia Dini, 1(2).

Strachan, S. L. (2015). Kindergarten students' social studies and content literacy learning from interactive read-alouds. Journal of Social Studies Research, 39(4), 207-223.

Susilaningsih, S., Abbas, N., \& Nurharini, A. (2018). Strategi Interactive Read Alouds dalam Optimalisasi Keterampilan Pemahaman Dongeng Anak di SDN 01 Tawangmas Semarang. Jurnal Penelitian PendidikanA \& A (Semarang), 35(1), 77-82.

Ustianingsih, L., Riwayanti, L. P., \& Malang, U. K. (2016). Pengaruh Metode Reading Aloud Terhadap Kemampuan Membaca Pemahaman Mahasiswa Jurusan Bahasa Jepang. Jurnal Ilmiah Bahasa Dan Sastra Unikama, 3(2), 542-551.

Vygotsky, L. S. (1986). Thought and Language. Cambridge: MIT Press.

Wilson \& Lonigan. (2010). Kemampuan Membaca dan Menulis di awal tahap tahap masa prasekolah atau literasi dasar.

Wirman, A., Yaswinda, Y., \& Tanjung, A. (2018). Jurnal Pendidikan: Early Childhood Nurhafizah Pendidikan merupakan proses. Early Childhood: Jurnal Pendidikan, 2(2), 1-10. 